\title{
Theorizing the (Un)Sounded in Sikhī: Anhad, Sabad, and Kïrtan
}

\author{
Inderjit N. Kaur
}

Citation: Kaur, Inderjit N. 2021. Theorizing the (Un)Sounded in Sikhī: Anhad, Sabad, and Kīrtan. Religions 12: 1007. https://doi.org/10.3390/ rel12111007

Academic Editor:

Heather MacLachlan

Received: 10 August 2021

Accepted: 14 October 2021

Published: 16 November 2021

Publisher's Note: MDPI stays neutral with regard to jurisdictional claims in published maps and institutional affiliations.

Copyright: (C) 2021 by the author. Licensee MDPI, Basel, Switzerland. This article is an open access article distributed under the terms and conditions of the Creative Commons Attribution (CC BY) license (https:// creativecommons.org/licenses/by/ $4.0 /)$.
Department of Musicology, University of Michigan, Ann Arbor, MI 48109, USA; inkaur@umich.edu

\begin{abstract}
Listening to sabad kīrtan (sung scriptural verse) is a core, everyday, widespread, and loved worship practice of Sikhs around the globe. Thus, it would be fair to state that sounding is central to Sikh worship. Indeed, the Sikh scripture considers kīrtan to be an eminent mode of devotion. Yet, the ultimate aim of this sonic practice is to sense the "unsounded" vibration - anhad - and thereby the divine and divine ethical virtues. Based on a close reading of Sikh sacred texts and ethnographic research, and drawing on the analytic of transduction, the paper explicates the embodied vibratory dimensions of the (unsounded) anhad and (sounded) sabad kïrtan. It argues that the central purpose of the Sikh (un)sounding perceptual practice is embodied ethical attunement for an unmediated experience of the divine and divine ethical virtues, and thereby the development of an ethical life. At the intersection of music, sound, religious, and philosophical studies, the analysis reveals the centrality of the body in worship and ethical development, and contributes to interdisciplinary conversations on sensory epistemologies in faith traditions.
\end{abstract}

Keywords: Sikh; sabad kīrtan; anhad; worship; sound; body; vibration; transduction

\section{Introduction}

The word sikh literally means student, and as a verb, it means to learn. A Sikh is a learner of Sikhī (lit. teachings; Sikhism, in English), the path to the divine, founded by Guru Nanak (1469-1539). The principal medium of Guru Nanak's communication, as that of his nine successors (1504-1708), was song. The Sikh Gurus canonized over 5000 of their songs, along with a few hundred known to be of poet-saints from other faiths (duly ascribed), into the Sikh scripture, the Guru Granth Sahib (lit. spiritual-preceptor book respected). Thus, and importantly for this paper, the primary Sikh scripture is essentially a sacred songbook, a compendium of about 6000 sabad (scriptural verse/s) without any prose. Importantly, too, the last Sikh Guru instituted this scripture as the only and eternal Guru of the Sikhs. One can say, therefore, that Sikhs are students of the wisdom contained in a sacred songbook.

The everyday singing and chanting of the scriptural verses (sabad kìrtan and pätth, respectively) is how Sikhs imbibe Sikhī. Additionally, these very songs emphasize that their repeated singing and listening are highly efficacious means of devotion to a divine that is understood as an ethical ideal, and thereby of the ethical shaping of the subject. Furthermore, musical metaphors abound in the sabad to express the nature of the divine and the experience of divine union. Foremost among these is the notion of anhad (lit. limitless), something that plays (such as music plays). The word nād, sound, is also used in the sabad in conjunction and interchangeably with anhad. There are other cognate terms such as anhad sabad (word), anhad bāni (word-utterance), anhad dhun (melody), and many more, several of which will come up below.

Given the importance of the idea of anhad in the Sikh scripture, scholars and community members alike have taken interest in interpreting it. ${ }^{1}$ To mention a few scholarly works, chronologically, Pashaura Singh has written that "this 'unstruck melody' ... cannot be directly perceived or 'heard,' although it is the basis of the entire perceptible world" 
(Singh 2006, p. 144). Arvind Pal Mandair has explained anhad sabad as "a mode of communication in which the mind speaks with itself, ... to rejoin the two aspects of the dualistic mind separated by ego-sense" (Mandair 2009, pp. 374-75). I have referred to anhad as "unstruck mystical vibrations", and stated that "[t]he ultimate purpose of Sikh shabad kirtan is to awaken in the participant vibrations sympathetic with anhad, and thereby to move beyond the sensory to the mystical - a state marked by peace and tranquility" (Kaur 2011b, p. 304). Subsequently, writing in more detail about the importance of listening and heeding in Sikhī, I have explored anhad as "unheard sound" and a "metaphor for ethical potential" (Kaur 2016a, pp. 30-33). There, I have argued that anhad is unheard in the sense that its ethical connotations become inaudible in the everyday preoccupation with the mundane but that it can be "heard" in the affective listening to the divine ethical virtues elaborated in sabad kirrtan, as well as in the form of embodied ethical action. In this account, the perception of anhad occurs indirectly in affective listening and in ethical action. Nikky-Guninder Kaur Singh, too, in a beautifully written essay on Sikh mysticism, has explicated the importance of hearing, including its ethical implications, and conceptualized the perception of anhad as indirectly heard as it echoes in the sounds of the world. She writes:

"The soundless sound is heard when the conscious hearing of the sounds of this multiverse hits the primal sound within ... Hearing enables comprehension of what lies outside and thus serves as a connector of the exterior with the interior self. This spontaneous resonance hearkens the unstruck sound, and all the sounds of the world, all the languages used by the various species, are heard as reverberations of that singular primal sound." (Singh 2017, p. 121)

This interpretation, like the earlier ones, understands the sensation of anhad as mediated and not direct-anhad is perceived in the aural hearing of external sounds.

In this paper, I join this conversation on anhad to propose that in the scriptural verses, the conceptualization of the perception of anhad, and thereby that of the divine, is different from the above interpretations, that it is described as a sensation that is directly a corporeal experience and an embodied process, physical and material. Additionally, I explicate that the sensation of anhad is an experience of the ethical principle of oneness, which, as I will elaborate later in the essay, necessarily involves the dissolution of boundaries, such as internal and external, and the self and the other. In the above-mentioned scholarship, the perception of anhad is either indirect, through the audition of external sounds or as embodied in ethical action, or it is psychological-mental. In my view, the rich palette of perceptual metaphors deployed in the Guru Granth Sahib cue us to a direct experience of anhad, and a body-sensorial epistemology of the divine and divine ethical virtues. As cognitive linguist George Lakoff and philosopher Mark Johnson have proposed in their conceptual metaphor theory (Lakoff and Johnson 1980), bodily experience, which is the basis of knowledge, becomes mapped onto the domain of linguistic expression. Cognitive psychologist Raymond Gibbs (Gibbs 2005, p. 9), too, has argued, "People's subjective felt experiences of their bodies in action provide part of the fundamental grounding for language and thought... Human language and thought emerge from recurring patterns of embodied activity." More recently, ethnomusicologists Thomas Porcello, Louise Meintjes, Ana Maria Ochoa, and David W. Samuels (Porcello et al. 2010) have argued for the recognition of the sensorial and social properties of language and for language as an embodied expressive practice.

Based on a close reading of Sikh scriptural verses and ethnographic research, I propose here that in the sacred songs, anhad is conceptualized as the common physical vibration in all entities in the universe, directly sensed in the body. Furthermore, the common vibration is the basis of the oneness of all-the belief that at the fundamental level there is no duality (i.e., separation of self and other, a point that will be elaborated below). The corporeal sensation of anhad is an unmediated embodied experience of this oneness. Finding the perception of anhad to be directly and physically in the body, I investigate the relationship between the (unsounded) anhad and (sounded) sabad to explore a perceptual 
epistemology of the divine and divine ethical virtues. The divine, as the very first sabad in the Guru Granth Sahib states, is an eternal truth, and the central question in seeking the divine is how to become truthful. The eternal truth is the oneness of humanity and the entire universe, encapsulated in the numeral 1 (१), the first entry in the scripture. This same oneness permeates each and every entity in the universe. The divine-the eternal truth and ultimate reality, is thus an ethical virtue, that of oneness. This ultimate reality and ethical principle, I interpret, become known in the physical experience of anhad, and sabad kirtan is a means to this experience.

My arguments proceed as follows. First, I elaborate on the embodied, ethical, and divine nature of anhad, and the reason for my translating it as the "unsounded" in contrast to the "sounded." Second, I explicate that (unsounded) anhad and (sounded) sabad have a symbiotic relationship, unpacking it in terms of a two-way transduction that aids a sensation of the divine and divine ethical virtues. Finally, I argue that this perceptual process is enhanced by sabad kīrtan, which is why kīrtan is regarded in the primary scripture as an eminent mode of worship. I elucidate that the efficacy of kirtan is due to the affective capability of "kìrtaning" in conditioning the body for heightened states of perception and knowledge. I use this neologism, in the manner of "musicking" (Small 1998), to include the actions of singing and listening. Kïrtan is something that Sikhs do and listen to. The word musicking itself does not convey the precise meaning since kïrtan cannot be simply translated to music, as it refers only to sung verses (see also Kaur 2011a).

\section{The Unsounded in Sikh Scripture}

In the Guru Granth Sahib, a number of sabad elaborate on the nature of anhad. Based on these, I summarize the salient attributes of anhad as follows. Anhad is physical vibration in the body-a sensation in the body, just as sound is physical vibration perceptible in the body. However, there are important differences. Sound is produced vibration; it is created by a process of one object striking another. Sound thus has a beginning and an end, and a form; it can be distinguished from another sound. In contrast, anhad is unproduced, formless, and limitless. It is undifferentiated vibration common to each entity in the universe. Furthermore, it encapsulates divine ethical virtues in terms of their fundamental premise, that of oneness. Epitomizing this eternal truth and ultimate reality of oneness, anhad is in fact a conceptualization and an experience of the divine.

These points have their bases in the sabad in the Guru Granth Sahib. As the verse below indicates, anhad plays and dwells in the body (ghar):

भठगट्र हाप्षै तिस याि हामा ॥ $(161)^{2}$

Anhad vājai nij ghar vāsā.

Anhad plays; dwells in one's own body-home.

The following lines add that anhad has no form or boundary. It is limitless:

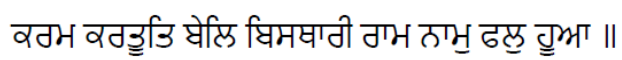

Karam karțūt bel bisthārī rām nām fal hūā.

Good actions have blossomed like a vine; divine remembrance has fruited.

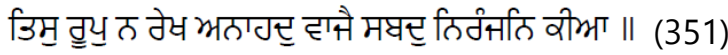

Tis rūp na rek $\underline{h}$ anāhad vājai sabad niranjan kīā.

In them, the formless, limitless, anhad plays; the sabad reveal the virtuous divine.

Anhad, the scriptural verses say, is something that "plays," and this gives it the connotation of music/sound. However, anhad does not play exactly like sound, which has form and is not limitless. Yet, like sound, anhad plays physically, not just metaphorically. In another verse, anhad is said to vibrate (jḩhunkāré). Thus, it is a physical occurrence, in the body: 


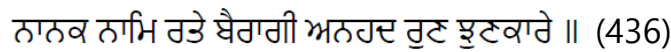

Nānak nām rate bairāgī anhad run j jhunkāre.

Says Nanak, in those immersed in divine ethical virtues, anhad vibrates.

Furthermore, this vibration is not produced by anyone. Referring to the body as a musical instrument, a sabad states:

दिट् टसाप्टी रिंगुठी टाजै नैगी मा रिंगुठी हसाप्टि ॥ (909)

Vin vajāì kingrī vājai jogī sā kingrī vajāe.

Let the body-fiddle play, O seeker (of the divine), as it plays without being played.

Thus, unlike sound, which is produced through a process of striking one object against another, anhad does not have a causal source-it is unsounded vibration. ${ }^{3}$ Unlike produced sound, which has decay, a beginning and an end, anhad is atemporal, limitless, and without boundaries. As formless and eternal vibration, each anhad vibration is the same as the other. In other words, anhad is undifferentiated vibration.

This undifferentiated vibration plays in each and every entity (ghat ghat) in the universe. As a sabad states:

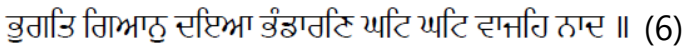

Bhugat giān daiā bhandāran ghat ghat vājëh nād.

(The divine) Nourishes with wisdom and compassion; in every entity plays nād (anhad).

Anhad is thus the common vibration in the universe. This idea is repeated time and again in the scriptural verses. N. Singh (2017), too, expresses a similar, though not as specific, understanding from the Guru Granth Sahib that "humans are made up of the same stuff as the rest of the universe; the physicality of each individual is integrated with the wider environment" (119). With respect to vibration specifically, the notion is also found in philosopher Elizabeth Grosz's writing that "[v]ibration is the common thread or rhythm running through the universe" (Grosz 2008, p. 54), and that "[t]he vibratory oscillations that constitute the universe" are "forces that cannot be distinguished or differentiated from each other" (5).

The common vibration in the universe is also conceptualized in the sabad as divine utterance, as in this verse:

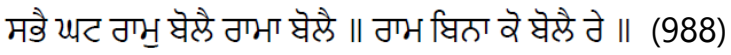

Sabhai ghat rām bolai rāmā bolai. Rām binā ko bolai re.

In every entity the divine speaks, none other but the divine.

Here, anhad vibration is what the divine speaks; it is divine utterance.

In the verses cited so far, anhad is also tied up with ethical virtues. In the verse above from page 351 of the scripture, anhad plays in a body in ethical action, i.e., it plays as ethical action, and in a body that remembers the divine. In the verses from page 436, anhad vibrates in those who are immersed in divine ethical virtues. Thus, we begin to see a perceptual epistemology of the divine and of divine ethical virtues.

The sabad also state that anhad and its attributes are those of the divine. An example of this is in the following line:

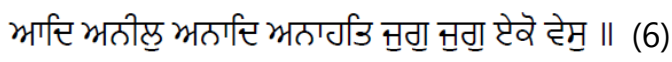

$\bar{A} \underline{d}$ anīl anād anāhat jug jug eko ves.

(The divine is) Primal, virtuous, without beginning, anhad; forever the one/same.

In this way, anhad can be understood as a conceptualization of the divine. As formless and undifferentiated, neither contains difference and hierarchy. This sameness, this equality, 
is the eternal truth of oneness. In this reality, there is no Other (dooja) - no one and nothing that is inferior. Elsewhere, I have called this the philosophy of non-Othering (Kaur forthcoming-b).

In this understanding, everyone and everything is unified and interconnected in nature's order (hukam). As a sabad states:

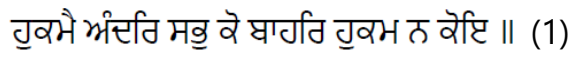

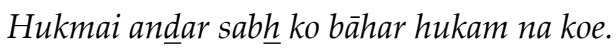

All is in nature's order; nothing is outside.

In contrast, there is the falsehood of duality in which the self is the center of the universe, and the rest, the Other, to be used to serve oneself. It is thus that the sabad consider self-centeredness and egotism ( ЈQిभै, haumai-I am) to be the biggest impediment to realizing the divine. Philosopher Keshav Singh has explained this lucidly:

"Fundamentally, haumai is a kind of false conception of oneself as singularly important, and correspondingly, a false conception of the world as revolving around oneself, as a world of objects there for one's use. It is, at its extreme, a kind of ethical solipsism: an inability to conceive of anyone or anything but oneself as an ethical subject." (Singh 2021, p. 320)

K. Singh thus argues that haumai is the "master vice" and "the source of human beings' separation from an ultimate reality on which we are radically interconnected" (320).

The body plays a critical role in the comprehension of this ethic. Numerous verses in the Guru Granth Sahib emphasize the body as the instrument for the experience of the divine and enaction of divine ethical qualities. The body is referenced, in fact, in terms of a variety of musical instruments that play anhad in divine attunement. When the body vibrates in tune with the eternal common vibration, the body plays as anhad kingri (fiddle), anhad toor (trumpet), anhad beena (lute), and anhad mridang (drum). The body is also referred to in terms of parts of musical instruments: tumba (gourd), which forms the resonating chamber of traditional South Asian stringed instruments, dandi (fingerboard), and tanti (string). Some sabad state that when the body-instrument is in tune with the divine, its tanti does not break. In other words, its vibrations do not lose attunement with the common vibration and divine ethical virtues. The attuned body-instrument's voicings are referred to as anhad sabad (word), anhad bāni (utterance), and anhad dhun (melody). These references to musical soundings, I propose, are not just abstract metaphors but refer to physical experiences and actions.

The theory, in the Sikh scripture, of embodied vibration, attunement to the divine, and ethical development comes together in the following sabad:

भैमी रिंगुठी हकाष्टि सेगी ॥

Ais̄̄ kingurī vajāe jogì.

Let that body-instrument play, O seeker,

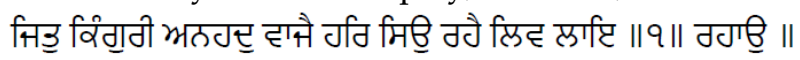

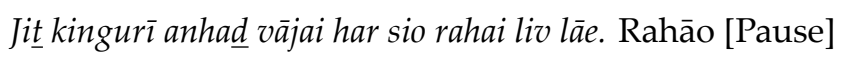

As the body in which anhad plays; stays in divine attunement.

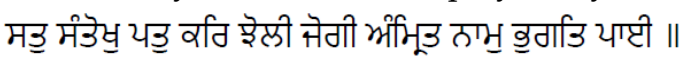

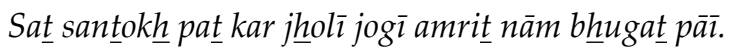

Gaining truth, contentment, dignity, O seeker; (the body) obtains divine eternal nourishment.

यिभात रा राि ईंडा सेती मिंशी मुर्णति दसाप्टी ॥२॥

Dhiān kā kar dandā jogì sińñ surat vajāi.

With care, O seeker, the body-instrument plays in (divine) awareness.

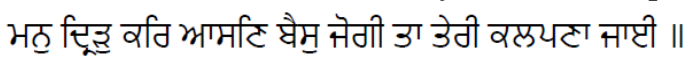

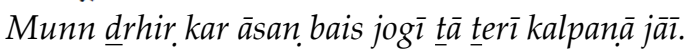

With determined attention, O seeker, (worldly) fantasies vanish. 
राप्टिभा ठठाठी भाि भंगाटि छर्रठ सेठी उा ठाभु यहै याप्टी ॥३॥

Kāiā nagrī mèh mangan charẹeh jogì țā nām palai pāà.

Seeking within the body, O seeker, the divine is accessed.

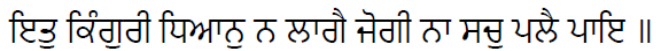

İ kingurī dhīān na lāgai jogì nà sach palai pāe.

(But) that body does not find awareness, O seeker, nor grasps the truth,

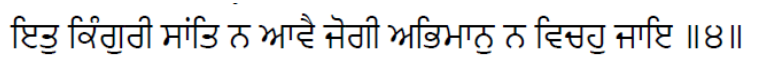

It kingurī sänt na àvai jogī abhimān na vichahu jāe.

That body does not find peace, $\mathrm{O}$ seeker, which cannot relinquish arrogance.

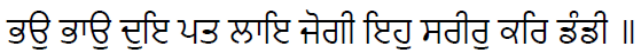

Bhao bhāo due pat lāe jogì ih sarìr kar dandì.

(So) make awe and love (of the divine) sound in your body-instrument,

O seeker.

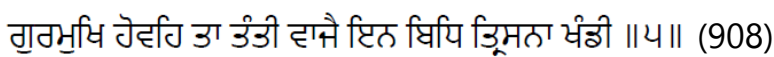

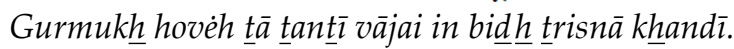

Only by becoming virtuous, the (attuned) body-instrument plays; in this way,

destroys (worldly) cravings.

This sabad says that the divine is accessed in the body. This body is one which vibrates in tune with the common vibration. In such a state, it perceives the truth of the oneness in the universe and experiences contentment with one's place in the natural order of things, rather than seeking to be the center of the universe. However, the body that does not vibrate in attunement with the common vibration, which is steeped in arrogance, cannot grasp the truth of oneness and access the divine.

To recapitulate the main points of this section, I have argued that in the scriptural verses, anhad is described as vibrations in the body that are unproduced, formless, undifferentiated, limitless, and atemporal. Thus, while they are vibrations, as is sound, they are not sounded (produced) vibrations (which sound is), and this is my basis for using the term unsounded for anhad. The qualities of anhad are the same as that of the divine; anhad vibrations embody the divine ethical virtue of oneness (the central philosophical tenet of Sikhī). Anhad is in fact described in the scriptural songs as an attribute of the divine and an experience of the divine. Together, all this leads me to say that anhad can be said to be a conceptualization of the divine.

\section{Between the Unsounded and the Sounded: Two-Way Transductions}

I now proceed to investigate the relationship of (unsounded) anhad to (sounded) sabad in the scriptural verses, and explicate how their reciprocity forms an (un)sonic perceptual and embodied epistemological system for comprehending the divine and divine ethical virtues. My exposition is based on recognizing both anhad and sabad as wholebody vibrations that are similar in ethical substance but different in terms of their form and temporality, and their cognitive and affective contents.

In the scriptural verses, there is a two-way symbiotic relationship between anhad and sabad. Sabad are understood as both derived from anhad, as well as possessing the capacity to engender the perception of anhad, i.e., sabad both come from and lead back toward anhad. A verse sates:

\section{माि ठार्ट घेर गुठवप्टी ॥ (879)}

Sabh nād bed gurbānī.

Vedas, Gurbani (Guru's Word, Sabad), are all (revealed) nād (anhad).

Sabad are, in fact, described as revealed divine utterance (dhur ki bāni). As another verse states:

गठि भाये मषट् मुर्णड प्रति भाये ॥

Har āpe sabad surat $\underline{d} \underline{h} u n$ āpe. 
The divine is itself (revealed as) the sabad, (as) sounded awareness.

If sabad is revealed divine utterance, and (as we have seen before from pages 988,6 , and 908) divine utterance-what the divine speaks (bolay) and plays (vājai) - is anhad, then sabad is revealed anhad.

In the reverse direction, sabad are believed to bring about the perception of anhad, as the following verses state:

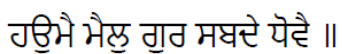

Haumai mael gur sabde dhovai.

The Guru's sabad removes egotism.

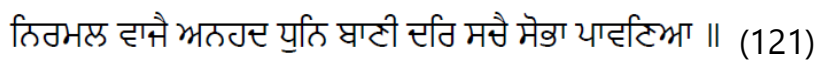

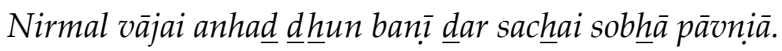

The virtuous anhad melody and utterance play, (one) finds the truth

(of oneness).

Here, sabad works by eradicating egoism, which is the main obstacle in comprehending the eternal truth of oneness.

This two-way epistemic process between (sounded) sabad and (unsounded) anhad is not simply cognitive-psychological but, in my interpretation, thoroughly embodied. To unpack this, I draw on the multidimensional analytic of transduction. Generally understood as some sort of conversion or transference, in the context of vibration, transduction is the process by which vibration traverses different media. It involves the conversion of energy from one form to another. ${ }^{4}$ As we well know, our hearing of sound involves the transduction of sound waves into nerve impulses. However, sound and hearing involve much more than our auditory apparatus. Moving beyond audist notions of sound and an ear-centric conceptualization of hearing, Deaf Studies and Sound Studies have emphasized sound as vibration in a material medium (Goodman 2010; Friedner and Helmreich 2012) and as inter-material vibration (Eidsheim 2015). The recognition of sound as vibration opens up our understanding of hearing as not just limited to the ear but a process that encompasses the entire body. As philosopher Michel Serres wrote:

"We hear through our skin and feet. We hear through our skull, abdomen and thorax. We hear through our muscles, nerves and tendons. Our body-box, strung tight, is covered head to toe with a tympanum. We live in noises and shouts, in sound waves just as much as in spaces, the organism is erected, anchors itself in space, a broad fold, a long braid, a halffull, half-empty box which echoes them. Plunged, drowned, submerged, tossed about, lost in infinite repercussions and reverberations and making sense of them through the body. Sometimes dissonant, often consonant, disturbed or harmonious. Resonating within us: a column of air and water and solids, three-dimensional space, tissue and skin, long and broad walls and patches, and wiring, running through them; moorings receptive to the lower frequencies, as though our bodies were the union of ear and orchestra, transmission and reception." (Serres 2009, p. 141)

(Sounded) sabad and (unsounded) anhad, both vibrations material and physically experienced in the body, permeate the body. Building on this recognition of an entire-body vibrational experience of anhad and sabad, and their two-way symbiotic relationship as described in the Guru Granth Sahib, I suggest that these two physical realities, anhad and sabad, both loaded with ethical content, come into contact as two types of vibratory energy in the body. In this contact zone, they can transform into one another. Anhad, a formless and infinite vibration, can transform into formed and finite sabad vibrations, and the latter can transform back to the former. This bi-directional transformation is what I call here a two-way transduction.

This two-way transduction in whole-body vibrational energy, I posit, is a rich epistemic process that traverses domains of knowing in and by the body-physical, mental, and social. The human body is a sensory transducer that is able to transcend binaries (Henriques 2003). With repeated sensations of two-way transductions between anhad and 
sabad vibrations, devotees can transcend feelings of self and other, and internal and external, even if for a moment. Immersion in the anhad-sabad transductory complex can "summon[s] up experiential realness," in the sense of being in an unmediated presence of a sensation or feeling (Helmreich 2015, p. 226), such as a presence of the divine. Anhad-sabad transductions can "mediate between different orders, ... place heterogeneous realities in contact, and ... become something different" (Mackenzie 2002, p. 18). In the body with anhad and sabad - two milieus with reciprocal information - "one milieu [can] serve[s] as the basis for another" (Deleuze and Guattari 1987, p. 313).

During the course of an interview, I asked an interlocutor, a devout Sikh in her midsixties, "When you refer to wāheguru [the divine], what is your conceptualization of wāheguru?" Her answer was, "Honestly ... when I think of wāheguru ... . to me it is a vibration ... . I feel it. Sometimes ... when I reach that stage ... especially in AKJ kīrtan ... I feel something going through my body" ${ }^{\prime \prime}$ (25 January 2015). My interlocutor's reference to the feeling of vibrations in her body, engendered by listening to sabad kīrtan, indicates a physical transformation in the body. The particular vibrations that feel like the divine happen only sometimes, she says, and only when she reaches "that stage." This stage in my interpretation is the one when sabad transduces to anhad, enabling one to directly sense anhad.

The metaphors in the scriptural verses of the divine speaking and of divine sound playing in each entity of the universe indicate, I think, the ability of sound vibrations to permeate our being and transduce across binaries and realms. The Guru's sabad, as a sounded form of the unsounded divine vibration, reveals a knowledge of the divine by elaborating on the eternal truth and ultimate reality of the oneness in the universe. It removes egotism to reveal this oneness (as seen above in the verse from the scriptural page 121). The conversion of the infinite vibration of anhad to the finite audible vibrations of sabad renders it accessible to the proximate senses. It also brings it in the domain of the discursive, while retaining the affective. In the reverse direction, the vibrations of sabad in the body merge back to formless and limitless vibration. This merging back is a release of the discursive and mental-cognitive, and an attunement of the body-sensorial.

The sabad themselves state that even sabad are useful only if they bring an intuitive awareness of the divine. As a verse states:

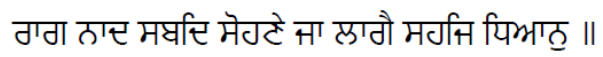

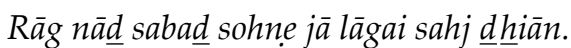

Melodies, sound, and sabad are beautiful only if they bring intuitive awareness

(of the divine).

गारा ठार हेनि गठि मेहीभौ उा रतगाव याप्टीभै भातू ॥ (849)

Rāg nāe chhod har sevīai tā â dargèh pāiai mān.

Only leaving behind the melodies and sound, can one realize the truth

(of oneness).

The second line above states that one must in fact move beyond the sounded. Ultimately, then, to experience formless vibration, the body has to register vibrations beyond those with form, i.e., beyond the sounded sabad themselves. Such an attunement is an embodied experience of anhad and the divine.

The sabad in fact urge each body-instrument to play anhad, as cited earlier, to vibrate as anhad. This physical and epistemic attunement is understood to occur through a process of repetition. "सय" (Jap-repeat; chant) is the first instruction in the scripture, on the first page, and occurs repeatedly within the scriptural verses. These sabad recommend one to constantly repeat the divine name, nām. Nām encapsulates ethical attributes of the divine, moving away from the discursive toward the affective. Such a continuous repetition approximates endlessness. The body is able to experience a temporal release from its sense of a separate self. A similar idea has been expressed by philosopher Edmund Burke (1767) that the sublime can be inspired by infinite repetition such as that found in waves and other natural patterns. 
In Sikh worship, the sounded vibrations of jap moves toward the unsounded vibrations of ajap jāp (spontaneous repetition) - the continuous vibration of anhad, and in that union, the divine is perceived. The repeated sounding of ethical values in the sabad, and in nām, accrues as material traces in the body, an intensification, an inscription of the sounded in the body's memory, of vibrations that transduce to anhad. Repeated listening is a subterranean practice that conditions the human sensorium through attunement and sedimentation (Hirschkind 2006). In the words of my interlocutor, "We need the repetitions. We need the intense persuasion. We need the sounds of kirtan to fill our bodies so we can hear wāheguru" (10 October 2014).

Indeed, the listening that is prescribed in the scriptural verses is an expansive one, sensorially and epistemically much more capacious than vibrations perceived and transduced only by the cochlea. The jap instruction in the opening page of the scripture is followed by a verse-composition referred to as the Jap. Considered the gist of Sikhī, its 38 verses, called pauri (step), lay out the steps to a spiritual path for realizing the divine. Verse 1 is on truth as the ultimate reality, verses 8-11 are on listening, and verses 12-15 on heeding and its significance and benefits. The following are excerpts from the verses on listening from pages $2-3$ of the scripture:

\section{मुटिभै पर्गड पहल भाराम ॥}

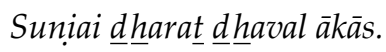

Listen to the earth, its foundation, the atmosphere.

मुटिभौ रीय सेम्भ याउाप्ल ॥

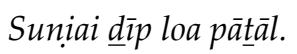

Listen to the oceans, the worlds, the subterranea.

मूटिभौ येगि 万 मवै राप्र ॥

Suniai poh na sakai kāl.

Listening, fear (of time, death) departs.

मुटिभै ट्रुध याय रा ठाम् ॥

Suniai $\underline{d} \bar{u} k \underline{h}$ pāp kā nās.

Listening, suffering and vices are destroyed.

मूटिभौ सेटा स्राराड उति केट ॥

Suniai jog jugat tan bhed.

Listen to the ways to unite, the ways of the body.

मुटिभै मठा गुटा वे ठाण ॥

Suniai sarā gunā ke gāh.

Listening, one dwells with virtues.

मुटिभौ गप वेहै भमठाग ॥

Suniai hāth hovai asgāh.

Listening, the fathomless is grasped.

These verses ask one to listen to vibrations beyond what is apprehended by the cochlea, to sense vibrations of the earth and the atmosphere, the body, and the limitless, timeless, and fathomless.

This "hearing" is heeding, and heeding brings awareness of the whole universe. The scriptural verses state:

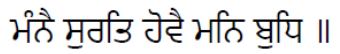

Mannai surat hovai man bud $\underline{d}$,

Heeding brings (divine) awareness to intelligence.

भंहै मठाप्ल कहट री मुयि ॥

Mannai sagal bhavan $k \bar{\imath}$ sud $\underline{h}$.

Heeding brings awareness of the entire universe. (3) 
This awareness of the universe from such hearing and heeding, I am arguing, is the awareness of the common vibration, and through that, an awareness of the truth of the oneness in the universe. The common vibration is an embodied sensation and reminder of the ethical interconnection of all entities in the universe, of one's embeddedness in the ultimate reality of the oneness in nature's order, and the imperative to play one's ethical role. Self-centeredness and Othering bring harm to wellness-environmental, societal, and personal. In this understanding, verses such as Sabai ghat rām bōlay-In each entity the divine speaks - sound the divine virtuous call of non-Othering.

\section{Congregational Musical Worship}

The scriptural verses also offer recommendations of practices that are considered most efficacious for enhancing the transduction process from sabad to anhad. The best means is considered to be kīrtaning - the singing of and listening to kīrtan, and repeatedly. As these verse excerpts state:

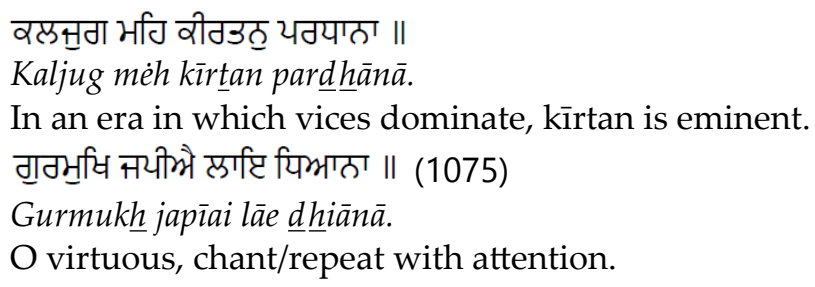

Another verse states:

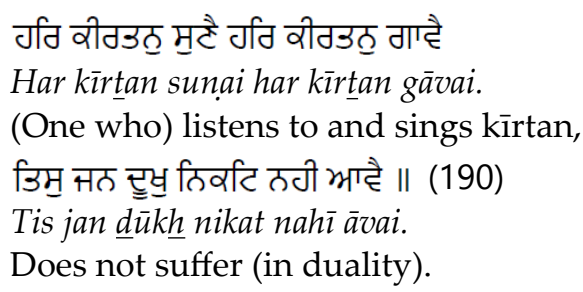

According to these verses, singing and listening to kīrtan is a way out of vices and suffering. The word kīrtan (kīrt + rt + tan; lit. praise + imbue + body) means the imbuing of the body with divine qualities. The repeated singing of divine ethical virtues is believed to sediment these in the body. In this section, I explicate how the practice of kîrtan is especially effective in the process of attuning the body's vibrations to anhad and, thereby, to divine ethical virtues. I argue that kīrtaning is an affective cultivation of the body to sense anhad.

Affect is a sensation of movement in the body; when we are affected, we are moved, we feel an intensity in the body (Massumi 2002). Musicking, as a movement of pitches in time, is by nature an affective process. It moves us and in us. The vibrations of kīrtan build as subterraneous intensities in the kīrtaning body. The special role of kîrtan singing and listening is thus in the accretion of affective force in the body. It is this visceral charge that heightens the perceptual faculties to apprehend anhad and the divine.

The efficaciousness of kīrtaning in amplifying affect comes also from repetition. We know that, as compared to speech, singing and listening to song often entails repetition, and we like this reiteration. "[F]amiliarity makes it possible for us to experience a sense of inhabiting the external sound" (Margulis 2014, p. 13). Thus, repetition provides "a transportive, and even transcendent kind of experience" (15).

Another critical factor, according to the scriptural verses and in practice, is the role of a pious congregation (sädh sangat). The company of the pious is considered so efficacious that a sabad states:

कप्टे यूगाम माप वै मंगा ॥ (287)

Bhae pargās sād $\underline{h}$ kai sang.

The divine is revealed in pious company. 
The congregational setting engenders intercorporeal affective transmission. As an interlocutor put it, "Sitting in the exquisite divan [Guru's court] hall in the Gurdwara Sahib [public place of worship], singing kīrtan in sangat makes me feel complete and calm, a part of an integrated beautiful community of resonance and oneness" (September 2019). Congregational kīrtaning infuses bodies and the surrounding atmosphere with sacred vibrations, affects, and transductions. The "material body ... resonates (with) its environment, creating and conducting affect" (Kapchan 2015, p. 41). Vibratory energy is transuded across bodies via the atmosphere. The aural rhythms of congregational kīrtan participation in particular have a "unifying, regulating role in affective exchanges" between devotees, "establishing and enhancing a sense of collective purpose and a common understanding" (Brennan 2004, p. 70). A visceral vibratory contagion of divine affects spreads intercorporeally and atmospherically, propelled by the discursive-affective force in the sacred texts and their sonic vibrations and trandsductions (Eisenlohr 2018).

Kīrtaning is thus a "somaesthetic" practice, one that cultivates the body for sensing its beautiful somatic experiences rather than sensing beauty in external aesthetic objects (Shusterman 2013). The beautiful and meaningful experiences in kīrtan participation are not located in pleasing musical sounds but in the bodily feelings of ras (flavor) (Kaur 2016a, pp. 45-47; forthcoming-a). The scriptural verses emphasize this, as in the following example:

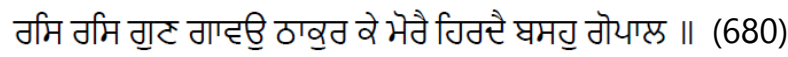

Ras ras gun gāvao thākur ke morai hirdai baso gopāl.

Ras-fully (savoring) sing of the virtues of the divine; the divine dwells in my heart.

My interlocutors have time and again expressed to me how important such ras-full experiences, often expressed as anand (bliss), are. In fact, for most, the very basis of authentic kīrtan is the generation of ethical affects such as humility and sincerity, rather than objectively construed melodic and rhythmic musical features (Kaur 2016b). Devotees have a certain distaste for singing that has any hint of arrogance. They know intuitively that any person or thing that embodies egotism, the basis for duality and Othering, is an impediment to the somatic experience of the divine. In the scriptural verses, pious affects are key for kīrtan to engender the experience of the divine and divine virtues, of anhad and anand. As a sabad sates:

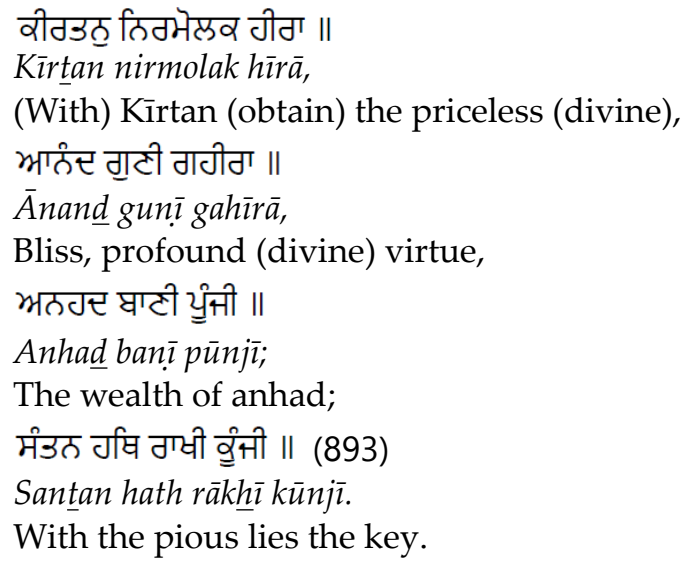

This experience of anand, of bliss, I am interpreting, is the result of liberation from form to formless, from limit to limitless, and from difference to oneness. It is the freedom from the shackles of haumai and dubidha (duality; lit. two modes-of the self and the other). It is the joy of experiencing one's unicity and interconnectedness in nature's order. Interlocutors have mentioned to me their experiences of anand but also that it is difficult to describe. As one interlocutor said, "There is no other feeling, only anand" (Bas, anand hee anand) (15 July 2012). The sabad also state that it is not possible to describe the experience of the union with the divine. In the words of another interlocutor, "When my mind goes 
blank ... that is when the sabad gets ingrained" (25 January 2015). This expresses that the experience of the divine that sabad engenders does not lend to cognitive and discursive capture. It is this release of the discursive and mental-cognitive that I am arguing is the move to anhad.

\section{Concluding Remarks: The Body as the Epistemic Site of the Divine}

In this paper, I have proposed that in Sikh culture, singing and listening to kīrtan is a physical conditioning of the body to viscerally sense anhad - the common vibration in the universe - and its ethical contents, most saliently, the oneness of all, and, thereby, the divine. Sikh kirtaning is a somaesthetic practice that prepares the body to physically sense and heed the ethical call in anhad that is elaborated in the scriptural verses. These verses (sabad) in turn are considered a sounding of the unsounded common vibration (anhad) in the universe. The sounding of anhad in sacred sabad reveals the ethical constituents and imperatives of this common vibration and the divine. Here, I have focused on the central ethic, that of oneness or non-duality, what I call non-Othering. Pious, congregational, sounded worship can arouse and make dominant the common unsounded vibration in the body-instrument; it can make the vibrations in the body-instrument in tune with the common vibration, so that the oneness can be perceived, heeded, and enacted. In this way, the sounded makes the unsounded heard. The process is affective and embodied at its core. This corporeal perception of anhad is sensed viscerally with the affect of anand (bliss), arising from relief from the pain of dubidha. Rather than only spiritual, psychological, or cognitive, as has often been emphasized, kīrtaning aims to stir up the body and cultivate it to unite its vibrations with the common vibration of oneness for an embodied sensation of divine ethical virtues and thereby the divine.

In explicating this point, I have made three critical interpretations regarding the relationship between the sounded (sabad) and unsounded (anhad) in the Sikh scriptural verses. First, I recognize that both are material vibrations in the physical body and perceivable by it, with the difference that the unsounded is not aurally perceptible, and is formless, undifferentiated vibration, common to everything in the universe. These attributes qualify it to be an aspect of a divine ethical ideal, one that accepts none as the Other. Reaching this non-Othering potential is an experience of or union with the divine. Second, I posit that the symbiotic relationship between anhad and sabad is a two-way transductory process between two whole-body vibratory experiences, and is loaded with reciprocal epistemic content pertaining to the divine - the ultimate truth and reality of the oneness of all. Third, I argue that sabad kîrtan is recognized in the scriptural verses as the eminent mode of worship due to its affective ability to condition the body to physically sense anhad, the common vibration of oneness permeating one's body and all bodies ${ }^{6}$.

Through these interpretations of Sikh scriptural verses, and explications of how anhad, divine ethical virtues, and the divine are conceptualized as experienced directly in the body as a material vibratory sensation of oneness, I have foregrounded the fundamental importance of the body in Sikh worship and Sikhī. In elaborating on the body as a site of a direct embodied perception of anhad and the divine, I extend scholarly interpretations of Sikh sacred verses, which have paid attention to the role of the body as elaborated in the scripture. Verne Dusenbery, writing on the controversies surrounding translations of the Sikh scripture, has argued insightfully that the Sikh Gurus (whose verses make up most of the scripture) "rather than merely dispensing religious homilies, ... serve up a more substantive fare: through channeling divine worship substances to the devotee, they transform the person in body as well as spirit" (Dusenbery 1992, p. 391). Here, I have argued that the scriptural verses are physically experienced material vibratory substances that can transduce in the devotees' bodies into the formless material vibration, anhad, enabling an unmediated embodied experience of the divine and the divine ethical virtue of oneness. In earlier work, writing on sabad kīrtan, I have discussed that "the experiences of sabad kīrtan listening and participatory singing" are "body sensorial" - "multisensorial, synaesthetic, affective, cognitive and somatic all at once, and they are engendered in an 
intersubjective setting" (Kaur 2016a, p. 18). N. Singh, writing on "Sikh Mysticism and Sensuous Reproductions," has elaborated beautifully on how, in the inaugural scriptural verses, "[O]ur attention is immediately drawn to the body, the corporeal and sensory aspects of the self," and how the scriptural verses throughout "invariably exalt[s] the body with its sensuous experience as the conduit for divine knowledge" (Singh 2017, p. 117). Here, I have argued that the body is not only a channel but also directly the site of divine knowledge.

The Sikh scriptural verses are shot through with body-sensorial metaphors. For devout Sikhs, the scripture is pragat Guraan ki deh-manifest form of the body of the 10 Sikh Gurus. The devotees refer to its pages not as panna (page) but as ang (limb/part). In its very form as a sacred songbook, and its emphasis on singing, listening, repeating, and vibrating, the scripture engages the sensorium as a fundamental epistemic site of the divine, not only a means of accessing it. It beckons to listen to the body, to the divine in the body:

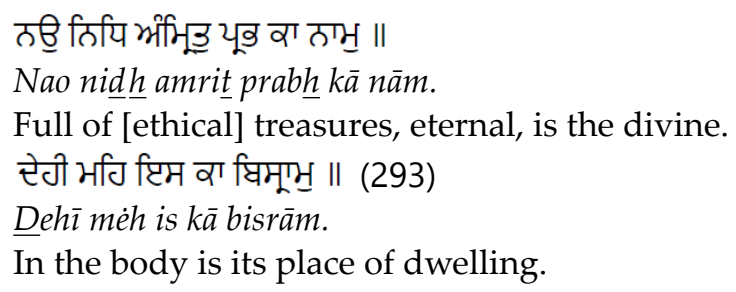

Funding: This research received no external funding.

Institutional Review Board Statement: The study was conducted according to the guidelines of the Declaration of Helsinki, and approved by the Institutional Review Board (or Ethics Committee) of the University of California, Berkeley (protocol number 2014-11-6852 and date of approval 14 December 2014).

Acknowledgments: I am grateful to Heather MacLachlan for inviting me to contribute to this special issue, and to the anonymous peer reviewers for very helpful comments.

Conflicts of Interest: The author declares no conflict of interest.

\section{Notes}

1 It is important to note here that in this paper I do not refer to similar terms as used in other Indic faiths. An in-depth comparison being outside the scope of this paper, I do not engage in any comparative remarks. Surface-level statements risk creating epistemological and cultural hierarchies, and can unwittingly become colonizing writing.

2 All verses quoted in this paper are from the Guru Granth Sahib, with page numbers indicated in the brackets. The translations are my own interpretations. The English transliterations are from srigranth.org, last accessed 8 September 2021.

3 Cultural studies scholar Steve Goodman (2010) uses "unsound" to refer to vibrations with frequencies outside the range of human audibility. My usage of "unsounded" is different in important ways. An essential attribute of anhad is that it is vibration not produced by anyone. Additionally, the negative connotation of "unsound" (not good, defective) is the opposite of what anhad is conceptualized as.

4 Transduction has been a productive analytic in sound studies and philosophy as well as disciplines such as biophysics, genetics, logic, and machine learning. Interestingly, James Gimzewski has pioneered the field of sonocytology, which converts the vibrations of living cells to audible sound.

5 AKJ stands for Akhand Kīrtani Jattha (lit. uninterrupted kīrtan singing group). In their kīrtan sessions, the singing of sabad is not interrupted by profane words such as program announcements and exegeses. The format is highly participatory with repeated cycles of musical intensification (see Kaur 2016a).

6 A question that may arise in readers' minds is whether the embodied epistemic capacity I have elaborated in the two-way transductions between (sounded) sabad and (unsounded) anhad are eliminated when sabad is read silently or chanted silently from memory, i.e., when sabad is experienced without sounding it, since this would take away one part of the vibrations from the sequence. My thinking on this is that while the processes might be diluted, embodied flows would still be activated in the felt-body from associations with prior sensing of the vibrations of sounded sabad. 


\section{References}

Brennan, Teresa. 2004. The Transmission of Affect. Ithaca: Cornell University Press.

Burke, Edmund. 1767. A Philosophical Enquiry into the Origin of Our Ideas of the Sublime and the Beautiful. London: J. Dodsley.

Deleuze, Gilles, and Félix Guattari. 1987. A Thousand Plateaus: Capitalism and Schizophrenia. Minneapolis: University of Minnesota Press.

Dusenbery, Verne A. 1992. The Word as Guru: Sikh Scripture and the Translation Controversy. History of Religions 31: 385-402. [CrossRef]

Eidsheim, Nina Sun. 2015. Sensing Sound: Singing E Listening as Vibrational Practice. Durham and London: Duke University Press.

Eisenlohr, Patrick. 2018. Sounding Islam: Voice, Media, and Sonic Atmospheres in an Indian Ocean World. Oakland: University of California Press.

Friedner, Michele, and Stefan Helmreich. 2012. When Deaf Studies Meets Sound Studies. Senses and Society 7: 72-86. [CrossRef]

Gibbs, Raymond. 2005. Embodiment and Cognitive Science. Cambridge: Cambridge University Press.

Goodman, Steve. 2010. Sonic Warfare Sound, Affect, and the Ecology of Fear. Cambridge: MIT Press.

Grosz, Elizabeth. 2008. Chaos, Territory, Art: Deleuze and the Framing of the Earth. New York: Columbia University Press.

Helmreich, Stefan. 2015. Transduction. In Keywords in Sound. Edited by David Novak and Matt Sakakeeny. Durham and London: Duke University Press.

Henriques, Julian. 2003. Sonic Dominance and the Reggae Sound System Session. In The Auditory Culture Reader. Edited by Michael Bull and Les Back. London and New York: Bloomsbury Academic.

Hirschkind, Charles. 2006. The Ethical Soundscape: Cassette Sermons and Counterpublics. New York: Columbia University Press.

Kapchan, Deborah. 2015. Body. In Keywords in Sound. Edited by David Novak and Matt Sakakeeny. Durham and London: Duke University Press.

Kaur, Inderjit N. 2011a. Sikh Shabad Kırtan and Gurmat Sangit: What's in the Name? Journal of Punjab Studies 18: 251-78.

Kaur, Inderjit N. 2011b. Musical Aesthetic in the Guru Granth and Implications for the Performance Practice of Sikh Shabad Kìrtan. Sikh Formations 7: 297-312. [CrossRef]

Kaur, Inderjit N. 2016a. When "Unheard Sound" (Re)Sounds: Affective Listening, Ethical Affects, and Embodied Experience in Sikh Sabad Kīrtan. Ph.D. dissertation, University of California, Berkeley, CA, USA.

Kaur, Inderjit N. 2016b. Multiple Authenticities in Motion: Styles and Stances in Sikh Sabad Kirtan. Yearbook of Traditional Music 48: 71-93. [CrossRef]

Kaur, Inderjit N. Forthcoming-a. Toward a Phenomenology of Ras(a): Theorizing from the Practice of Sikh Sabad Kīrtan. In The Oxford Handbook of Phenomenological Ethnomusicology. Edited by Harris Berger, Friedlind Riedel and David Vander Hamm. Oxford: Oxford University Press.

Kaur, Inderjit N. Forthcoming-b. Sabad Kīrtan, Langar, and the Affective Embodied Experience of Non-Othering in Sikh Practice. In Music and Dance as Everyday South Asia. Edited by Sarah Morelli and Zoe Sherinian. Oxford: Oxford University Press.

Lakoff, George, and Mark Johnson. 1980. Conceptual Metaphor in Everyday Language. The Journal of Philosophy 77: 453-86. [CrossRef] Mackenzie, Adrian. 2002. Transductions: Bodies and Machines at Speed. London: Continuum.

Mandair, Arvind Pal Singh. 2009. Religion and the Spectre of the West. New York: Columbia Univesity Press.

Margulis, Elizabeth. 2014. On Repeat: How Music Plays the Mind. New York: Oxford University Press.

Massumi, Brian. 2002. Parables for the Virtual: Movement, Affect, Sensation. Durham: Duke University Press.

Porcello, Thomas, Louise Meintjes, Ana Maria Ochoa, and David Samuels. 2010. The Reorganization of the Sensory World. Annual Review of Anthropology 39: 51-66. [CrossRef]

Serres, Michel. 2009. The Five Senses: A Philosophy of Mingled Bodies. London: Bloomsbury Publishing.

Shusterman, Richard. 2013. Thinking through the Body: Essays in Somaesthetics. Cambridge: Cambridge University Press.

Singh, Keshav. 2021. Vice and Virtue in Sikh Ethics. The Monist 104: 319-36. [CrossRef]

Singh, Nikky-Guninder Kaur. 2017. Sikh Mysticism and Sensuous Reproductions. In Ineffability: An Exercise in Comparative Philosophy of Religion. Edited by Timothy D. Knepper and Leah E. Kalmanson. Cham: Springer, pp. 113-34.

Singh, Pashaura. 2006. Sikhism and Music. In Sacred Sound: Experiencing Music in World Religions. Edited by Guy L. Beck. Waterloo: Wilfrid Laurier University Press.

Small, Christopher. 1998. Musicking: The Meanings of Performing and Listening. Middletown: Wesleyan University Press. 